\title{
The Value Evaluation System and Applications of Digital Cultural Resources
}

\author{
Yanan Gao ${ }^{1}$, Kang Kang ${ }^{2}$, Shiyong Kang ${ }^{3}$, Xiaoyu Wu ${ }^{1}$ \\ ${ }^{1}$ School of Information Engineering, \\ Communication University of China, Beijing \\ ${ }^{2}$ Communiction Engineering, \\ Waseda University, Japan \\ ${ }^{3}$ Chinese Natural Language Processing, \\ Lu Dong University, China
}

\begin{abstract}
This paper discussed the situation of value system of digital cultural resources at present. Through a variety of researches about methods of value evaluation, digital cultural resources are discussed and defined briefly. And its values are estimate depending on its own characteristics of different digital cultural resources. The particularity of the digital culture resources, its value indicators, using the analytic hierarchy process (AHP), Delphi method, and the user survey method to estimate the value of cultural resources are then studied. Finally the appropriate value evaluation system of digital culture resources is established. Taking an example to test it is right. It provided the value system with a good reference views for its future studies, provided a strong support to its acquisition, organization, management and services. So that it could lead the sharing of nationwide digital cultural resources and promote the construction of public culture service system as well.
\end{abstract}

Keywords-culture resources; value estimate; value factor; AHP; delphi method

\section{I.INTRODUCTION}

At present, there is no unified value estimation method for digital culture resources. Digital culture resources to enter the market to become a commodity circulation, such as the process of trading in the digital copyright and digital cultural resources, will involve the transaction price of the cultural resources [1]. It needs to have a reasonable price accurately, to establish a complete set of digital culture resources value estimation system.

\section{Cultural resources $\longrightarrow$ Cultural assets $\longrightarrow$ Cultural products $\longrightarrow$ Cultural goods}

Figure 1. The figure of the flow chart of digital cultural resource pricing

\section{THE CLASSIFICATION OF THE DIGITAL CULTURE RESOURCES}

The digitization of resources is divided into two categories: the first is the digitization of traditional cultural resources, which end up to digital products (such as digitization of cultural resources in National Library of China or National Museum of China); the second type is directly in the form of the digital cultural goods (e.g., network novel).

\section{THE FLOW CHART OF THE INDUSTRIALIZATION OF THE DIGITAL CULTURE}

To price a type of digital cultural resources, first of all, we should change the resources through the industrialization process into the products that can be priced, then through the market adjustment and various trading models we determine a reasonable price. So the first thing is to systematical review the entire industry.

For the digital process, the following figure 1 is cultural industrialization process:

In the practical transaction, the digitization of resources is divided into two categories: the first is the digitization of traditional cultural resources digitization, which end up to digital products (such as digitization of cultural resources in National Library of China or National Museum of China). The second type is directly in the form of the digital cultural goods (e.g., network novel). And this project mainly discussed the first category, the digitization of traditional cultural resources. So the definition of digital cultural resources will be the digital process of traditional cultural resources.

\section{THE DEFINITION AND CONTACT BETWEEN ANY PARTS OF INDUSTRIALIZATION OF DIGITAL CULTURE}

\section{A. Resources to assets}

As for cultural resources, mainly considering its social value, the public value and influences, it does not need to make qualitative judgment of its economic value. Like a photo, it is a work as well as cultural resources, the first thing is to turn it into an asset, which means we should clear and definite the rights of the photographer, including the rights of the thought to sell, the capability to sell, and the confirmation of the buyer's thought and action to buy. For problems of stipulating the rights, we should use the application mechanism of copyright and corresponding means of credit promotion, and thus make it into a tradable item through the standard framework. In addition, from resources to assets, it involved right ownership problems. So the next step is the process of the promotion of credit digital copyright. 


\section{B. Assets to the product}

By standardized packaging, cultural assets become cultural products. Cultural assets mainly consider its value assessment, covering the participants, previous investment, policy, and the prospective market, previous and prospective revenue. In practice, we use the cost method and income method, change assets into the use of products [2].

\section{Products to the goods}

Products entered the circulation after confirmation of their prices. And then, after confirming that buyers' and sellers' rights to trade, we use specific pricing methods and pricing model to price the goods. Finally, products can be converted to goods and take part in the market transactions. After arriving at the intention to make a deal, it should make sure the form and quality of the deal in the delivery payment link. In addition, we should consider that in what way, how often we pay. Later in the rights protection link, the relevant institutions supervise the buyer to confirm if it has the right to use all the purchases, and whether he or she is beyond the scope of right to use and so on.

\section{Goods}

In the aspect of cultural products, we mainly consider trading patterns or trading model, generally use the way of disposable trading or long-term trading, the purpose is to form the flow of goods into the economic circle, and coordinate the benign development of the business operations. And trade pattern will in turn affect the commodity pricing and value evaluation.

To sum up, because the digital copyright is a unique field, which has little comparability with ordinary goods, this article has a relatively clear systematical arrangement. In a word, cultural resources to the asset level are about the resource value assessment. In cultural product level, it is assessed by the pricing method, identifying its initial price. In cultural commodity level, it is to consider the market, trading patterns, adjust the final price-the market pricing.

\section{DigitAl CULTURE RESOURCE ASSESSMENT PROCEDURES}

This research uses the analytic hierarchy process (AHP) [3], Delphi method [4], and the user survey method to estimate the value of the digital culture resources. Now, let's take electronic books of "See" as an example and compare the price on the douban (a website in China) reader terminal.

(1) For the digital books, assess the factors which influence the value and get the value index.

(2) Using Delphi method to get expert advice and scores, with 1 to 4 according to experts on the evaluation of the index weight. As shown in Table 1, the value index of "See":

TABLE I. THE VALUe INDEX OF “SEE”.

\begin{tabular}{|c|c|c|c|c|c|c|}
\hline \multicolumn{2}{|c|}{ Influence Factor } & $\begin{array}{r}\text { Percentage } \\
(P)\end{array}$ & $\begin{array}{c}4 \\
\left(X_{1}\right)\end{array}$ & $\begin{array}{c}3 \\
(X\end{array}$ & $\begin{array}{c}2 \\
X\end{array}$ & $\begin{array}{r}1 \\
X\end{array}$ \\
\hline \multirow{3}{*}{$\begin{array}{l}\text { Content value } \\
\qquad \begin{array}{l}\left(Y_{1}\right) \\
0.3856\end{array}\end{array}$} & $\begin{array}{l}\text { Abundance } \\
\qquad\left(P_{1}\right)\end{array}$ & 0.0253 & Very abundant & $\begin{array}{c}\text { Quite } \\
\text { abundant }\end{array}$ & A little abundant & Not abundant \\
\hline & $\begin{array}{l}\text { Authority } \\
\qquad\left(P_{2}\right)\end{array}$ & 0.0919 & Very high & Quite high & Common & No \\
\hline & $\begin{array}{l}\text { Update } \\
\text { frequency } \\
\quad\left(P_{4}\right)\end{array}$ & 0.0253 & Very high & Common & Low & No \\
\hline $\begin{array}{l}\text { Property value } \\
\qquad\left(Y_{2}\right) \\
0.0895\end{array}$ & $\begin{array}{l}\text { Usability } \\
\left(P_{5}\right)\end{array}$ & 0.0746 & Very & Common & Low & No \\
\hline \multirow{2}{*}{$\begin{array}{l}\text { Visual value } \\
\left(Y_{3}\right) 0.0734\end{array}$} & $\begin{array}{l}\text { Novelty } \\
\left(P_{7}\right)\end{array}$ & 0.0367 & $\begin{array}{c}\text { Enterprise original, } \\
\text { without copying and } \\
\text { imitation }\end{array}$ & $\begin{array}{l}\text { Partial } \\
\text { imitation }\end{array}$ & $\begin{array}{c}\text { Large-scale } \\
\text { imitation }\end{array}$ & $\begin{array}{l}\text { Complete } \\
\text { plagiarism }\end{array}$ \\
\hline & $\begin{array}{l}\text { Epidemicity } \\
\qquad\left(P_{8}\right)\end{array}$ & 0.0367 & Very high & Quite high & Common & No \\
\hline $\begin{array}{c}\text { Browsing } \\
\text { experience } \\
\left(Y_{4}\right)\end{array}$ & $\begin{array}{c}\text { Recommendation and } \\
\text { introduction } \\
\left(P_{9}\right)\end{array}$ & 0.0054 & $\begin{array}{l}\text { Set up a takeaway, and } \\
\text { provide wonderful } \\
\text { content } \\
\text { recommendations }\end{array}$ & Quite high & Common & No \\
\hline
\end{tabular}




\begin{tabular}{|c|c|c|c|c|c|c|}
\hline 0.0323 & $\begin{array}{l}\text { Clean-slate design } \\
\left(P_{10}\right)\end{array}$ & 0.0269 & Fine & Common & Low & No \\
\hline \multirow{3}{*}{$\begin{array}{c}\text { Interaction } \\
\text { experience } \\
\left(Y_{5}\right) \\
0.2087\end{array}$} & $\begin{array}{l}\text { Convenience } \\
\qquad\left(P_{11}\right)\end{array}$ & 0.0393 & $\begin{array}{l}\text { User does not need to } \\
\text { learn professionally }\end{array}$ & $\begin{array}{c}\text { The user } \\
\text { needs a small } \\
\text { amount } \\
\text { involved }\end{array}$ & $\begin{array}{l}\text { Users need } \\
\text { instructions }\end{array}$ & $\begin{array}{l}\text { Users do not } \\
\text { know how to } \\
\text { operate }\end{array}$ \\
\hline & $\begin{array}{l}\text { Answers and feedback } \\
\qquad\left(P_{12}\right)\end{array}$ & 0.0169 & $\begin{array}{l}\text { The background can } \\
\text { timely feedback and } \\
\text { reply }\end{array}$ & $\begin{array}{l}\text { Common } \\
\text { speed }\end{array}$ & Low speed & No feedback \\
\hline & $\begin{array}{c}\text { Convenience of } \\
\text { information searching } \\
\qquad\left(P_{13}\right)\end{array}$ & 0.1525 & $\begin{array}{c}\text { Can show a clear list } \\
\text { and relevant characters } \\
\text { in different colors to } \\
\text { distinguish }\end{array}$ & Quite & Little & No \\
\hline \multirow{2}{*}{$\begin{array}{c}\text { Emotional } \\
\text { experience } \\
\left(Y_{6}\right) \\
0.0393\end{array}$} & $\begin{array}{l}\text { Friendly interface } \\
\qquad\left(P_{14}\right)\end{array}$ & 0.0066 & $\begin{array}{l}\text { giving users a variety of } \\
\text { greeting friendly tip, }\end{array}$ & Quite many & Low & No \\
\hline & $\begin{array}{l}\text { User engagement } \\
\qquad\left(P_{15}\right)\end{array}$ & 0.0328 & Very broad & Quite broad & Common & No \\
\hline \multirow{2}{*}{$\begin{array}{l}\text { Trust experience } \\
\qquad \begin{array}{c}\left(Y_{7}\right) \\
0.1712\end{array}\end{array}$} & $\begin{array}{l}\text { Reliability } \\
\qquad\left(P_{16}\right)\end{array}$ & 0.0856 & $\begin{array}{l}\text { The reliability of the } \\
\text { information content and } \\
\text { the operation is } \\
\text { extremely high }\end{array}$ & Quite high & Common & Low \\
\hline & $\begin{array}{l}\text { Safety } \\
\left(P_{17}\right)\end{array}$ & 0.0856 & Well protected & Common & Low & No \\
\hline
\end{tabular}

(3)User Survey Method [5]: Analyzing the feedbacks of users' questionnaires (407 copies). Then sorting the importance of the value of indexes of digital book, get the base of comparison matrix.

Content Value $>$ Interaction Experience $>$ Trust Experience $>$ Property Value $>$ Visual Value $>$ Emotional Experience $>$ Browsing Experience. The important degree on price is: 9 (Very Important); 7 (Quite Important); 5 (A Little Important); 3 (Not So Important); 1 (Not Important).

Given the result as follows:

9: Content Value

7: Interaction Experience, Trust Experience

5: Property Value, Visual Value

3: Emotional Experience, Browsing Experience

(a) AHP: Taking the result above into YAAHP to analysis and calculate the weight of each index as shown as Figures 2 and 3.

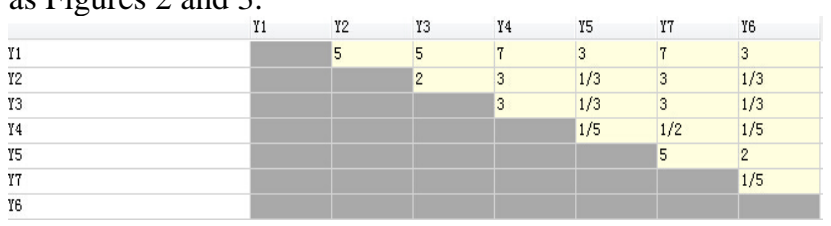

Figure 2. Judgment matrix of value

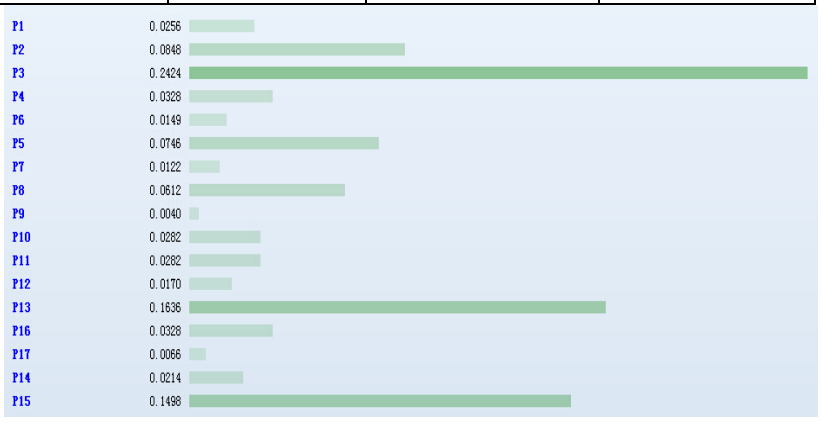

Figure 3. The weight of value index

(b) For a specified digital cultural resources, we determine the specific variables, then plug in pricing formula, it is concluded that the final price:

$$
P=A * \sum_{j=1}^{17} X_{i} P_{j}
$$

$P$ is the price of the digital book; $A$ is a constant, means price. $X_{i}$ is variables, namely the value system of each variable in the corresponding grade; $i=1,2,3,4, P_{j}$ is the weight, $j=1,2,3, \ldots, 17$

Issuing questionnaires (100 copies) to users to know that people's willingness to pay for this book is 3-15 yuan. So $A$ is:

$$
A=(3+15) / 2 * 2.5=3.6 \text { (yuan) }
$$

Then based on the corresponding weights in the price formula and value system, obtain the final price is:

$$
P=3.6 * 3.4175=12.303 \text { (yuan) }
$$


So according to the method in this paper, calculated result of the digital books of "See" is CNY 12.303, and the price on the website of douban (a website in China) is CNY 10.50, the prices have no big difference, so the method was established.

\section{SUMMARY}

This article through to the value of the digital culture resources estimation, integrated use of three kinds of ways, and an example is given to prove the validity of the method. An estimation for the future provides strong theoretical basis. But there are still some shortages, at present only in the e-book, would be to verify in other ways, augmented digital cultural resources to adapt to the range of value estimation system.

\section{ACKNOWLEDGMENTS}

This work is supported by the project of National Science and Technology of China, a subject one of it: The research of digital cultural resources for public service and commercial operations of the parallel and mutually beneficial operating mode (2012BAH01F01-01) and the project of Research of Large General Corpus Building for the Dictionary Compilation (11YJA740040).

\section{REFERENCES}

[1] Lambert M. Surhone, Mariam T. Tennoe, Susan F. Henssonow, Digital Britain Final Report. Majesty's Stationery Office, UK, 6, 2009.

[2] Yu Koseki, Hiroyuki Shimizu, Jun Iio, Business ecosystem for digital museums. IEEE, 2000

[3] Jie Zhang, The research of digital resources long-term preservation comprehensive, evaluation method. Northeast Normal University, 5, 2010.

[4] Noboru Maeda, Managing the Real Business for Digital Economy. ICMIT 2000, 2000.

[5] Chung-Shing Lee, Nicholas S. Vonortas, Business Model Innovation in the Digital Economy. Irwin, IL, 2004. 